\title{
Distribution and Generic Composition of Lytic Enzyme-Producing Bacteria in Coastal and Oceanic Bottom Sediments ${ }^{* 1,2}$
}

\author{
Isao Sugahara, ${ }^{* 3}$ Toshio Kimura, ${ }^{* 3}$ Koichiro Hayashi, ${ }^{* 3}$ \\ and Ichiro Nakajima*3 \\ (Received October 1, 1987)
}

\begin{abstract}
Distribution and generic composition of lytic enzyme-producing bacteria in coastal and pelagic bottom sediments of Japan were studied.

Bacteria capable of producing lytic enzymes were in the range of $10^{1}-10^{4} \mathrm{cfu}$ per $1 \mathrm{~g}$ of wet bottom muds. The average percentage of the number of lytic enzyme-producing bacteria to that of heterotrophic ones was $12.1 \%$.

Out of 482 strains of lytic enzyme-producing bacteria isolated from bottom sediments of Ise Bay, Matoya Bay, Owase Bay, Kumano Nada, Nansei Shotō and the surrounding area, Bacillus $(87.3 \%)$ was the most dominant bacterial genus.
\end{abstract}

Microorganisms capable of producing bacteriolytic enzymes seem to be distributed widely in marine environment.

Nair et al. ${ }^{12}$ reported that the percent of bacteriolytic strains in the seawater isolates was 24 $52 \%$ at Tokyo, Sagami and Suruga Bays of Japan. The percentage of bacteriolytic strains was higher in the bacteria isolated from zooplankton than those from seawater. ${ }^{1)}$ A lytic bacterial population forms colonies on fresh organic particles more than detrital matter that have been subjected to initial decomposition process. ${ }^{1)}$ They suggested that bacteriolytic enzymes may contribute to the initial decomposition of organic matter. ${ }^{1)}$

Little information on the ecology of lytic enzyme-producing bacteria in marine bottom muds has been available to date.

The present paper deals with the distribution and generic composition of lytic enzyme-producing bacteria in neritic and pelagic bottom sediments.

\section{Methods}

\section{Collection of Bottom Sediment Samples}

The bottom sediment samples from Ise Bay, Kumano Nada, Nansei Shoto and the surrounding area were collected during the cruises of 83-R2, 86-R-3 and $86-$ R-9 by the Seisui-Maru of Mie University.
Fig. 1 shows the location of sampling stations.

\section{Enumeration of Bacterial Number}

The opaque agar plate medium which contains Micrococcus luteus cells was used for counting the marine bacteria capable of lysing the bacterial cells. The medium used in this study was composed of polypepton (Daigo Eiyō Kagaku), $5.0 \mathrm{~g}$ : yeast extract (Nakarai Chemicals), $5.0 \mathrm{~g}$ : Micrococcus luteus cells (Seikagaku Kōgyō), $1.0 \mathrm{~g}$ (dry weight): agar, $15.0 \mathrm{~g}: 100 \mathrm{~m} l$ tap water and $900 \mathrm{~m} l$ seawater, pH 7.0. Bottom sediment samples were diluted to $10-10^{4}$ times with sterilized aged seawater, and aliquots of $0.1 \mathrm{~m} l$ from each dilution was spread on the surfaces of opaque agar plates. All plates inoculated were incubated at $25^{\circ} \mathrm{C}$ for 2-7 days. The bacteria capable of lysing bacterial cells formed the transparent zone around the colonies on the opaque agar medium containing heat-killed cells of Micrococcus luteus.

\section{Identification of Bacterial Strains}

Four hundred eighty-two colonies were isolated randomly from opaque agar plates for counting bacteriolytic bacteria. The bacteriolytic bacterial isolates were purified by streaking on opaque agar plates containing $M$. luteus heat-killed cells. The generic composition of the isolates was determined according to the scheme of Simidu ${ }^{2)}$ and to Bergey's Manuals. ${ }^{3-5)}$

*1 Studies on Marine Bacteria Producing Lytic Enzymes-XVI.

*2 Contribution from training ship Seisui-Maru, Mie University.

*3 Faculty of Bioresources, Mie University, Tsu 514, Japan (菅原庸, 木村俊夫, 林孝市郎, 中捣一郎: 三 重大学生物资源学部). 


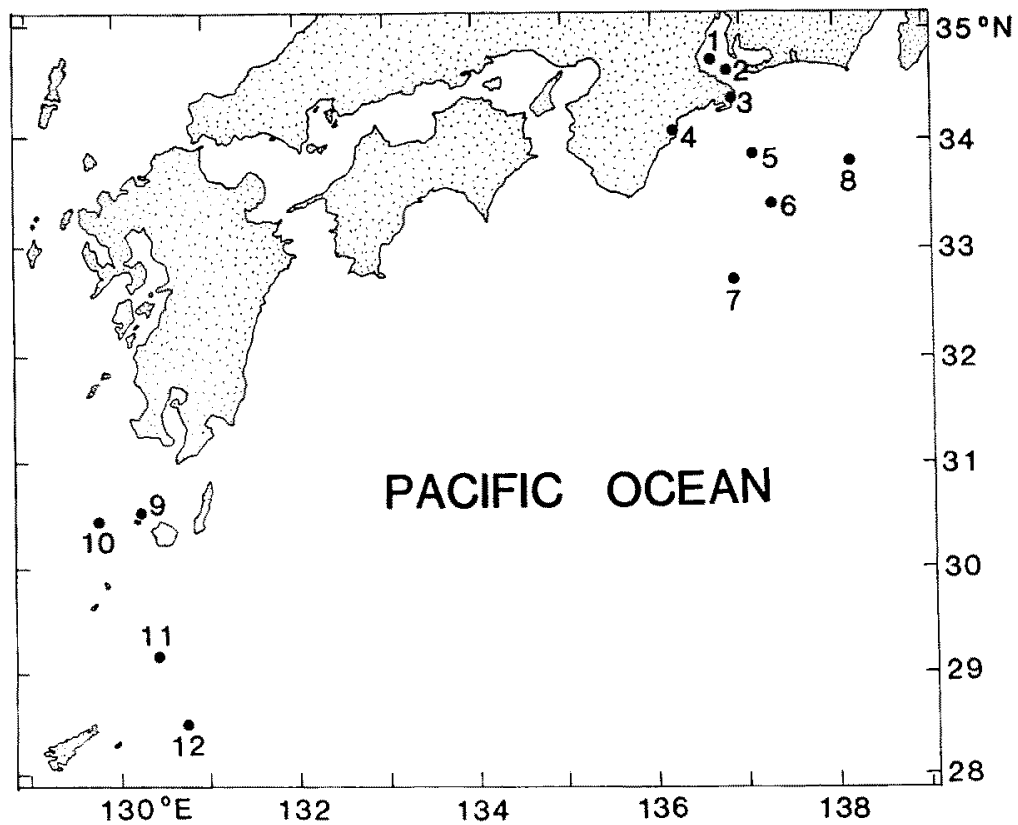

Fig. 1. Location of sampling stations set up in coastal and oceanic regions of Japan.

Table 1. Distribution of lytic enzyme-producing bacteria in the bottom sediments of Kumano Nada and its surrounding area

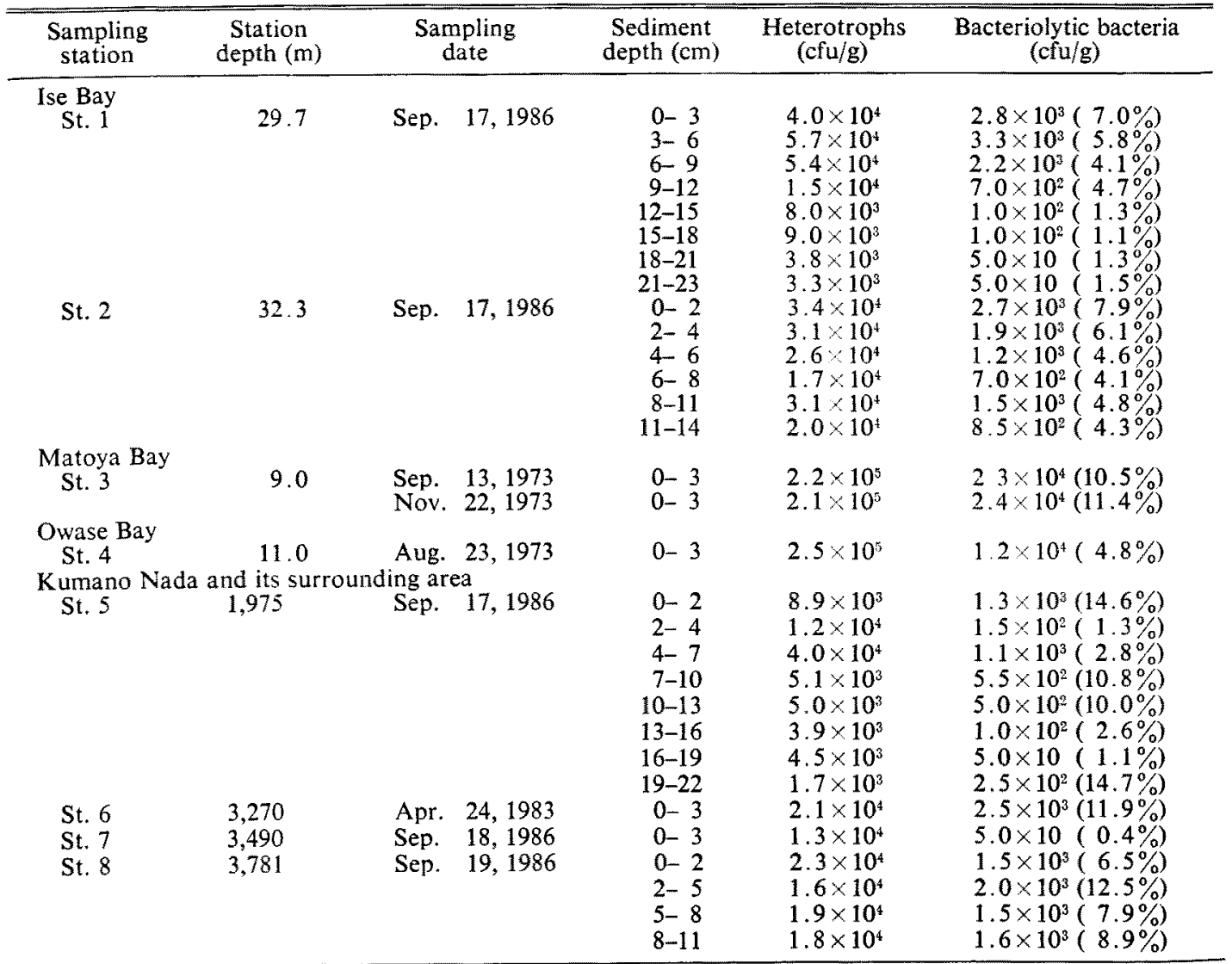

Values in parentheses show the percentage of the number of lytic enzyme-producing bacteria to that of heterotrophic bacteria. 


\section{Results}

\section{Distribution of Lytic Enzyme-Producing Bacteria}

As shown in Table 1, heterotrophic bacteria usually occurred at the level of $10^{3}-10^{5} \mathrm{cfu}$ per
$1 \mathrm{~g}$ of wet bottom sediment, but they were more abundant in enclosed bays, such as Ise, Matoya and Owase Bays. Bacteria capable of producing lytic enzymes were in the range of $10^{1}-10^{4} \mathrm{cfu} / \mathrm{g}$ in Kumano Nada and the surrounding area.

Table 2. Distribution of lytic enzyme-producing bacteria in the bottom sediments of the Nansei Shotō area

\begin{tabular}{|c|c|c|c|c|c|c|}
\hline $\begin{array}{l}\text { Sampling } \\
\text { station }\end{array}$ & $\begin{array}{l}\text { Station } \\
\text { depth } \\
\text { (m) }\end{array}$ & $\begin{array}{c}\text { Temp. of } \\
\text { bottom } \\
\text { water }\left({ }^{\circ} \mathrm{C}\right)\end{array}$ & $\begin{array}{c}\text { Sampling } \\
\text { date }\end{array}$ & $\begin{array}{l}\text { Sediment } \\
\text { depth } \\
\text { (cm) }\end{array}$ & $\begin{array}{l}\text { Heterotrophs } \\
\quad(\mathrm{cfu} / \mathrm{g})\end{array}$ & $\begin{array}{l}\text { Bacteriolytic bacteria } \\
(\mathrm{cfu} / \mathrm{g})\end{array}$ \\
\hline St. 9 & 533 & 8.0 & May 10,1986 & $0-3$ & $1.1 \times 10^{3}$ & $4.0 \times 10^{2}(36.4 \%)$ \\
\hline St. 10 & 679 & 6.5 & May 10,1986 & $0-3$ & $3.8 \times 10^{3}$ & $6.0 \times 10^{2}(15.8 \%)$ \\
\hline \multirow[t]{9}{*}{ St. 11} & 2,263 & 1.8 & May 10,1986 & $0-2$ & $5.4 \times 10^{3}$ & $8.0 \times 10^{2}(14.8 \%)$ \\
\hline & & & & $2-5$ & $3.1 \times 10^{3}$ & $1.0 \times 10^{3}(32.3 \%)$ \\
\hline & & & & $5-8$ & $1.7 \times 10^{3}$ & $7.5 \times 10^{2}(44.1 \%)$ \\
\hline & & & & $8-11$ & $9.5 \times 10^{\circ}$ & $2.5 \times 10^{2}(26.3 \%)$ \\
\hline & & & & $11-14$ & $9.5 \times 10^{2}$ & $1.0 \times 10^{2}(10.5 \%)$ \\
\hline & & & & $14-17$ & $4.5 \times 10^{3}$ & $\mathrm{ND}^{*}$ \\
\hline & & & & $17-20$ & $5.0 \times 10$ & $\mathrm{ND}^{*}$ \\
\hline & & & & $23-27$ & $1.5 \times 10^{2}$ & ND* \\
\hline & & & & $27-33$ & $5.0 \times 10$ & $\mathrm{ND}^{*}$ \\
\hline \multirow[t]{4}{*}{ St. 12} & 2,875 & 1.5 & May 9,1986 & $0-2$ & $4.2 \times 10^{3}$ & $1.1 \times 10^{3}(26.2 \%)$ \\
\hline & & & & $2-5$ & $2.6 \times 10^{3}$ & $7.0 \times 10^{2}(26.9 \%)$ \\
\hline & & & & $5-8$ & $3.8 \times 10^{3}$ & $1.3 \times 10^{3}(34.2 \%)$ \\
\hline & & & & $8-14$ & $7.0 \times 10^{2}$ & $3.5 \times 10^{2}(50.0 \%)$ \\
\hline
\end{tabular}

Values in parentheses show the percentage of the number of lytic enzyme-producing bacteria to that of heterotrophic bacteria.

ND*: Not detected.

Table 3. Morphological and physiological characteristics of the lytic enzyme-producing bacteria isolated from bottom sediments of coastal and pelagic regions of Japan

\begin{tabular}{|c|c|c|c|c|}
\hline & $\begin{array}{l}\text { Ise, Matoya and } \\
\text { Owase Bays }\end{array}$ & $\begin{array}{c}\text { Kumano Nada } \\
\text { area }\end{array}$ & $\begin{array}{l}\text { Nansei Shotō } \\
\text { area }\end{array}$ & Total \\
\hline Number of strains tested & 328 & 80 & 74 & $482(100.0 \%)$ \\
\hline Form rods & 320 & 80 & 74 & $474(98.3 \%)$ \\
\hline $\operatorname{cocci}$ & 8 & 0 & 0 & $8(1.7 \%)$ \\
\hline Gram positive & 321 & 77 & 65 & $463(96.1 \%)$ \\
\hline negative & 7 & 3 & 9 & $19(3.9 \%)$ \\
\hline Flagella polar & 1 & 0 & 0 & $1(0.2 \%)$ \\
\hline lateral & 10 & 1 & 1 & $12(2.5 \%)$ \\
\hline peritrichous & 288 & 78 & 62 & $428(88.8 \%)$ \\
\hline Spore formation & 304 & 76 & 41 & $421(87.3 \%)$ \\
\hline Catalase positive & 328 & 80 & 74 & $482(100.0 \%)$ \\
\hline Oxidase positive & 297 & 80 & 72 & $449(93.2 \%)$ \\
\hline Pigmentation & 30 & 12 & 6 & $48(10.0 \%)$ \\
\hline Indole formation & 0 & 0 & 0 & $0(0 \%)$ \\
\hline M. R. positive & 114 & 22 & 39 & $175(36.3 \%)$ \\
\hline V.P. positive & 232 & 66 & 17 & $315(65.4 \%)$ \\
\hline Nitrate reduction & 147 & 51 & 45 & $243(50.4 \%)$ \\
\hline Denitrification & 2 & 0 & 0 & $2(0.4 \%)$ \\
\hline Growth in $0 \% \mathrm{NaCl}$ & 318 & 75 & 47 & $440(91.3 \%)$ \\
\hline Heat resistance & & & & \\
\hline$\left(100^{\circ} \mathrm{C}, 30 \mathrm{~min}\right)$ & 304 & 76 & 41 & $421(87.3 \%)$ \\
\hline Starch hydrolysis & 124 & 34 & 12 & $170(35.3 \%)$ \\
\hline Gelatin liquefaction & 317 & 80 & 35 & $432(89.6 \%)$ \\
\hline Growth at $5^{\circ} \mathrm{C}$ & 60 & 27 & 5 & $92(19.1 \%)$ \\
\hline
\end{tabular}


Table 2 shows the distribution of lytic enzymeproducing bacteria in the bottom sediments of the Nansei Shotō area. The number of bacteria capable of lysing bacterial cells was $10^{2}-10^{3} \mathrm{cfu}$ per $1 \mathrm{~g}$ of wet bottom sediment. There was no distinct tendency of the vertical distribution of heterotrophic bacteria and lytic enzyme-producing ones in the sediment column.

The percentage of the number of lytic enzymeproducing bacteria to that of heterotrophic bacteria ranged from 0.4 to $14.7 \%$ in the Kumano Nada and its surrounding area, and from 10 to $50 \%$ in the Nansei Shoto area. The average percentage of bacteriolytic strains was $12.1 \%$.

Generic Composition of Lytic Enzyme-Producing Bacteria in Bottom Sediments

Out of 482 strains of lytic enzyme-producing bacteria, 328 strains were isolated from enclosed bays (Ise, Matoya and Owase Bays), 80 strains from Kumano Nada and its surrounding area, and 74 strains from Nansei Shotō area.

As shown in Table 3, the majority of the isolates were spore-forming, gram positive rods with peritrichous flagella. About $91.3 \%$ of the isolates did not require $\mathrm{NaCl}$ for growth. About $89.6 \%$ of the bacterial strains are capable of liquefying gelatin and $35.3 \%$ can hydrolyse starch.

Table 4 lists the generic composition of lytic enzyme-producing bacteria isolated from coastal and oceanic bottom sediments. Bacillus was the most dominant bacterial genus in the bottom sediments. An unknown bacterial group which is gram positive, asporogenous motile rod with mainly peritrichous flagella comprised $7.1 \%$ of the isolated lytic enzyme-producing bacteria. Most of them have been considered as members of Brevibacterium. However, according to Bergey's Manual, s) Brevibacterium is a gram positive, asporogenous non-motile aerobic bacterium with a marked rod-coccus cycle. Further study is necessary in order to demonstrate taxonomical characteristics of an unknown bacterial group isolated during this study.

\section{Discussion}

Johnson et $a l^{8)}$ isolated heterotrophic bacteria belonging to genera of Pseudomonas, Achromobacter, Vibrio, Flavobacterium, Hyphomicrobium, Bacillus and Brevibacterium from bottom muds of the Indian Ocean. Wood ${ }^{7)}$ also isolated Staphylococcus, Sarcina, Corynebacterium and Mycoplana from marine muds of eastern Australia. Bacterial members belonging to the genera Pseudomonas and Aeromonas were isolated from deep-sea sediments collected at depths from 9,400 to $10,400 \mathrm{~m}$ in the Philippine and Marianas Trenches of the Pacific Ocean. ${ }^{8)}$ On the other hand, Hayashi ${ }^{9)}$ studied heterotrophic bacterial flora in the bottom sediments of the Kumano Nada in Japan. According to him, ${ }^{, 1}$ Bacillus (about $30-75 \%$ ) was the most dominant bacterial genus. The unknown bacterial group which is gram positive, asporogenous motile rod with peritrichous flagella was also abundant (about $16-29 \%$ of the total heterotrophic isolates). ${ }^{8)}$ Gram positive bacteria including Bacillus, Corynebacterium, Micrococcus and the unknown bacteria comprised about 68 $97 \%$ of total isolates from bottom sediments of the Kumano Nada $(480-3,470 \mathrm{~m} \text { in depth. })^{9)}$ The generic composition of lytic enzyme-producing bacteria is almost similar to that of sediment heterotrophic bacteria in the Kumano Nada.

Gram negative rods, such as Pseudomonas, Vibrio, Alcaligenes, Flavobacterium and Acinetobacter-Moraxella are generally dominant heterotrophic bacterial members in the water, ${ }^{10)}$ although gram positive microorganisms, such as Bacillus, Micrococcus and coryneforms are abund-

Table 4. Generic composition of the lytic enzyme-producing bacteria isolated from bottom sediments of coastal and oceanic regions of Japan

\begin{tabular}{lcccr}
\hline & $\begin{array}{c}\text { Ise, Matoya and } \\
\text { Owase Bays }\end{array}$ & $\begin{array}{c}\text { Kumano Nada } \\
\text { area }\end{array}$ & $\begin{array}{c}\text { Nansei Shotō } \\
\text { area }\end{array}$ & Total \\
\hline Number of strains tested & 328 & 80 & 74 & $482(100.0 \%)$ \\
\hline Bacillus & 304 & 76 & 41 & $421(87.3 \%)$ \\
Micrococcus & 8 & 0 & 0 & $8(1.7 \%)$ \\
Alcaligenes & 5 & 2 & 5 & $12(2.5 \%)$ \\
Moraxella & 0 & 0 & 4 & $4(2 \%)$ \\
Flavobacterium & 1 & 1 & 0 & $2(7 \%)$ \\
Pseudomonas & 1 & 0 & $0.8 \%$ & $1(2 \%)$ \\
Unknown & 9 & 1 & 24 & $34(7.1 \%)$ \\
\hline
\end{tabular}


ant in the bottom sediments. ${ }^{9)}$

Nair et al. ${ }^{1)}$ studied bacteriolytic bacteria isolated from seawater, particulate materials and plankton of Tokyo, Sagami and Suruga Bays. The major bacteriolytic group was Pseudomonas at Sagami and Suruga Bays, whereas it was Vibrio at Tokyo Bay. ${ }^{1)}$ However, in this study, gram negative rods, such as Alcaligenes, Moraxella, Flavobacterium and Pseudomonas were minor components of lytic enzyme-producing bacteria in the bottom sediments.

Nair et al. ${ }^{1)}$ also indicated that about $24-52 \%$ of the bacterial isolates obtained from seawater of Tokyo, Sagami and Suruga Bays of Japan were capable of lysing Vibrio parahaemolyticus cells. More than $60 \%$ of the isolates from zooplankton produced lytic enzymes. ${ }^{1)}$ In this study, the average percentage of bacteriolytic strains in marine sediments was $12.1 \%$. The differences in percentage of bacteriolytic strains may be due to the differences in the substrate cells used for detecting lytic activity.

The temperature of water exceeding $1,000 \mathrm{~m}$ in depth is below $5^{\circ} \mathrm{C}$ in coastal and pelagic regions. ${ }^{11}$ About $19.1 \%$ (92 strains) of the bacteriolytic isolates (482 strains) from bottom sediments were able to grow at $5^{\circ} \mathrm{C}$. This value $(19.1 \%)$ seems to be rather low, probably due to the incubation temperature $\left(25-30^{\circ} \mathrm{C}\right)$ used when bacteriolytic bacteria were firstly isolated from marine sediments.

Most of bacteriolytic isolates from marine sediments were Bacillus sp. It is still unknown, however, whether Bacillus species exist in the state of the vegetative cells or spore. A significance of lytic enzymes and their role in marine environment are also not yet clear. Further study on the lytic enzyme-producing bacteria is necessary from the viewpoint of marine ecology.

\section{References}

1) S. Nair, K. Tsukamoto, and U. Simidu: Nippon Suisan Gakkaishi, 51, 1469-1473 (1985).

2) U. Simidu: Mar. Sci., 5, 588-594 (1973).

3) R.E. Buchanan and N.E. Gibbons: Bergey's Manual of Determinative Bacteriology, 8th ed., Williams and Wilkins, Baltimore, 1974, p. 1246.

4) N. R. Krieg and J. G. Holt: Bergey's Manual of Systematic Bacteriology, Vol. 1, Williams and Wilkins, Baltimore, 1984, pp. 1-964.

5) P. H. A. Sneath, N. S. Mair, M. E. Sharpe, and J. G. Holt: Bergey's Manual of Systematic Bacteriology, Vol. 2, Williams and Wilkins, Baltimore, 1986, pp. 965-1599.

6) R. M. Johnson, R. M. Schwent, and W. Press: Limnol. Oceanogr., 13, 656-664 (1968).

7) E. J. F. Wood: Aust. J. mar. Freshwat. Res., 4, 160-200 (1953).

8) M. M. Quigley and R. R. Colwell: J. Bacteriol., 95, 211-220 (1968).

9) K. Hayashi: In "Microbiological Aspects in Aquaculture" (ed. by A. Kawai), Koseisha Koseikaku, Tokyo, 1986, pp. 38-47.

10) I. Sugahara, L. C. Lim, and K. K. Hooi: Nippon Suisan Gakkaishi, 50, 1385-1393 (1984).

11) C. E. ZoBell: In "Marine Microbiology," Chronica Botanica Co., Waltham, Massachusetts, 1946, p. 240. 